\title{
ACTIVE SOCIAL PROGRAMS DEVELOPMENT IN BULGARIA: CONTEMPORARY CHALLENGES AND SOCIAL MANAGEMENT INSTRUMENTS
}

\author{
Venelin Terziev \\ Corresponding Member of the Russian Academy of Natural History, Moscow, Russia, Prof. D.Sc. \\ (Ec.), D.Sc. (National Security), D.Sc. (Social Activities), Ph.D., National Military University, Veliko \\ Tarnovo, Bulgaria; University of Rousse, Rousse, Bulgaria, terziev@skmat.com
}

\begin{abstract}
The study presented comes as a result and in response to the identified priorities of the social policy in Bulgaria and logically outlines the actions for an effective management of the social processes tailored to the dynamic social environment. The essential characteristics of the social policy, its relations with the social management and the opportunities for it to become a way of realization of important public tasks gives the chance to fit in it more delicate and important problems and the associated solutions. For this reason, the achievement of an active labor market is perceived as an objective of the social management, reachable in the conduct of relevant social policies, reflecting the registered interests of interested parties and society's need for an appropriate and irreversible change. The actually active social programs, interpreted as a system of social projects with direct feedback of social interaction, define the possibilities for adaptation of their components to the coming changes.
\end{abstract}

Keywords: social policies, social programs, labor market.

\section{INTRODUCTION}

Under the conditions of the formation of information society new theoretical approaches are formed, a new model of active, dynamic self-improving social programs is developed. These social programs are capable of active self-improvement and adjustment to the dynamically changing conditions of social life. In addition to the fact that under the new conditions the real need of orientation of the social programs towards solution to the problems of intellectual educational development increases, the characteristics of health and physical development do not lose their social significance. Today, public health is a real indicator of a country's wealth, a reflection of the quality of life and the level of development of human resources. The state of health is directly related to the income per capita and the maintenance of the healthcare system.

In market conditions, the modern social programs have many manifestations. In turn, they have specific 
principles, methods, technologies for identifying and reaching social goals, ways and means of development of human resources. The general trend in the development and implementation of social programs for human resource development is the fact that their preponderant target orientation is related to solving the problem of the health and physical development of the population, the intellectual and educational development of human resources.

The implementation of the social programs under the conditions of the modern market system requires not only a deep knowledge and understanding of its nature and essence, but also creative skills when using the specific forms of the given method of social control. And that means to develop and implement detailed technological procedures for the creation of social programs and their implementation in accordance with the principles of systematic social management.

The objective preference for participation in active social programs, synthesizing active projects, considered as a complex of flowing projects, based on social processes directed to human development. The social processes based on active programming and projection is of unbalanced, dynamic nature and that is why they are at the forefront of the active social programs. The basis of the social resources for support of the programs may be conditionally structured as a combination of at least three layers of support. Taken together, these three layers form a space of flows of social resources for support. The first layer, the first resource basis of the space of flows, consists of a chain of electronic impulses (telecommunication, computer processing systems for broadcasting and highspeed transport based information technology). The second layer of the space of flows is composed of hubs and communication centers. These are mostly large social institutions, which link the global network for support of social projects. The third important layer of the space of flows refers to the spatial organization of the dominant managerial elite, performing management functions, around which the organizational space is built.

Technocratic, financial and management elites that occupy a leading position in our society, also have their specific spatial requirements regarding the material and spatial basis of their interests and actions.

In the new conditions, the development of programs requires setting in the mechanism of their implementation of an active research and pioneering work for their self-cultivation. The adequacy of the program-targeted social management under the conditions of unstable and constantly changing way of life, is manifested in its focus to active examination of the results from the implementation of the social program (social assessment of the results from the implementation), attracting large groups of the population for its development.

The active social program is a system of social projects with direct feedback from social interaction that determines the adaptive capacity of the components of the program to the changing requirements to it. Moreover, in connection with the implementation of the social program, its social goals, implementation terms, partially its participants could be changed, as well as its attracted social resource to be transformed.

Under the current conditions, the active social programs in their essence reflect the transition from the traditional to the innovative model of social development. This transition namely determines the integrated use of social programs within the frames of innovative creativity, partner relations of participants within the program, the delegation of auxiliary functions to structures and collaborators, as well as widespread public participation of the population in the implementation of the programs.

\section{CHALLENGES TO ACTIVE SOCIAL POLICIES: THE CASE OF BULGARIA}

In recent years, significant efforts have been made for execution of the tasks arising from the commitments of Bulgaria to the European Union strategic priorities. In many areas of labor, employment and social security relations significant steps towards the harmonization of the legislation with the European and social practice have been made. The legislation and practices in the field of employment and combating unemployment are constantly improving in view of harmonization with the directives and regulations of the EU and the successful achievement of the Europe 2020 goals. Gradually, the effects of the active measures on the labor market have been enhanced and the institutional capacity improved. However, the accumulated problems in the field of employment and combating unemployment are difficult to overcome. The economic activity of the population and the employment rate of the labor force in the country are lagging behind compared to the EU average. The difficulties in the social policy in Bulgaria are related to several circumstances: in the first place, the relatively short period, for which the social model in the country had to be radically changed; in the second place, the low socio-economic level in Bulgaria that makes necessary the adaptation to higher goals, objectives and social standards; in the third place, the fact that the very European social policy is under continuous expansion and enrichment of adopting new principles, approaches and specific recommendations to the member states. Some of the main challenges for the social policy of Bulgaria are: the trinity "education, employment, standard of living” to be regarded as a leading 
practice in the socio-political practice; conditions for higher quality of life of Bulgarian citizens to be created, given the limited financial resources for health, education and security; the social policy to become a factor for productivity, which means new investments in human capital. These challenges require a qualitative change of the system for social protection. Measures to motivate and encourage citizens to be more active and autonomous should be included in it. Assuming the general principles and spirit of the European social policy, Bulgaria should comply with its national specifics and traditions.

The country is facing a serious challenge to improve the Bulgarian social model and the need to bring it into line with the EU legislation. In this regard, the following priorities of the social policy and the employment policy in Bulgaria can be formulated for the next years:

- Increasing income and bringing closer the quality of life through an active social policy, consistent with the criteria, standards and achievements of the EU;

- Increasing the labor income;

- Continuation of the reforms in the pension system;

- Conducting an active social policy to overcome the negative demographic trends, targeted investment in the social development of children and young people and creation of equal opportunities for social reproduction;

- Providing equal opportunities, prevention and elimination of discrimination based on sex, age, disability, ethnicity, etc.

- Conducting an active policy of training and promoting employment for disadvantaged people in the labor market;

- Ensuring social protection and integration of vulnerable groups of the population;

- Stimulating links between universities and the business and a life-long learning;

- Reducing regional disparities.

Moreover, now, when the country is an equal member of the euro structures and the European social policy plays an important role in building the economic strength of the EU through the development of a unique social model, the improvement of the European social model and investing in people is important to the preservation of the European social values of solidarity and justice while improving the economic achievements. The social policy of the EU, which has begun its development as an extension and complement of the economic policy, is gradually becoming more important for the functioning of the Community and takes its place as one of the most important areas of activity of the Union.

\section{SOCIAL PROGRAMMING AND SOCIAL MANAGEMENT}

Studies, analyses, summaries and forecasts allow deriving the following cross-cutting implications accompanied by more specific suggestions.

The modern consideration of programming as a general principle of management is associated with preliminary planned future actions and activities aimed at achieving a certain goal with certain means, in accordance with the challenges of the dynamic changes in the social environment on the basis of alternativeness of the decisions and optimal choice, contributing to the management by results.

The concretization of the objectives of the social management is carried out through the social program, as a structured dynamic image and a way of action for coordinated interaction between the bodies of power, which allows the solution of important social problems according to their resource commitment, executors and deadlines for the implementation of a set of tasks and measures.

The effectiveness (economic and social) of the operating and developing social system, is always the result of the actions of all factors of the system as a whole, presented as an integrative productivity. Consistency and complexity of the relationship between economic and social efficiency is determined by the methodological principle, which states that the implementation of the social program becomes in itself a catalyst for effective socio-economic development.

The validity of the objectives and tasks to assess the effectiveness of social services in Bulgaria, to provide stability and support to disadvantaged people, known as risk groups, is determined by the analytical capabilities of the social service for identification and evaluation of the "inquiries”, the resource availability of the social service to meet the „inquiries”; the level of interaction between the institutions at a state (national), municipal and non-governmental level; socio-economic conditions and qualifications of the collaborators of 
the social service.

The theoretical and pragmatic overview of social programming allows the application of an appropriate methodology for the development of an active social program, which primary goal is determined by the faster level of knowledge, prediction and achievement of socially significant consequences for the future in the forming of the general public process.

For the assessment of the effectiveness of the social program, the determination of exact criteria, specific reference points and specific indicators is necessary, which can serve as formally adopted standards for social service and as parameters of the program itself.

The people, the human resources with their actions and skills are a key factor of the social policies. The confirmation of this is the fact that the remaining components of a country's resources are synthesized and multiplied in them and thus turned into a finished product in the planning of the goals of the socioeconomic development, enabling an effective social policy.

In an environment of dynamic changes, requiring the participation of human resources in the socio-economic processes, through maintenance and development of adequate to the changes in the social environment capabilities to harmonize social relations, the need to establish an effective system of social activity is determined, which essential characteristics are the change, activities, social subject, social system, social relations.

The active role of socialization is determined by the creative activity of the human personality in the course of the gained social experience and the reproduction of a certain system of social relations.

Achieving an active labor market as a result, united by the overall objective of a social management as an active social policy, determines the adaptation of the model for collective qualifications on the basis of which to reveal the potential of the individual and the society, through the implementation of active social programs for social protection in the dynamically changing social environment.

In the early periods of development of the labor market, its policies aim primarily at tackling the effects of the economic reforms on employment, but the policy of the labor market today has a clearly distinguished active character and is aimed at influencing processes or formation of behavior among target groups according to preliminary planned targets. The functioning labor market in the country is an adequate mechanism of the market environment and the conducted policy complies increasingly with the existing relationships and interactions between the periods of development of the economy and the labor market.

\section{METHODOLOGY OF ACTIVE SOCIAL PROGRAMS DEVELOPMENT}

The active social program, as a system of social projects with direct feedback from social interaction, determines the adaptive capacity of the components of the program to the changing demands to it. Their unifying social idea is a synthesis of thoughts, ideas and objectives of the participants in the program, including representatives and members of the public (Terziev, 2017, $318 \mathrm{str}$; Terziev, Arabska, 2016, $312 \mathrm{str}$; Terziev, 2018, 307 p.; Terziev, 2015, 110 p.; Terziev, 2015a, 434 p.; Terziev, Arabska, 2015b, 198 p.; Terziev, Arabska, 2015c; Terziev, Arabska, 2014, str. 3-57; Terziev, 2015d; Terziev, Georgiev, 2018a, str. 970-975; Terziev, Georgiev, 2018b, str. 959-969; Terziev, Georgiev, 2018c, str. 951-958; Terziev, Georgiev, 2018d, str. 188-193; Terziev, Georgiev, 2018e, str. 177-187; Terziev, Georgiev, 2018f, str. 169-176; Terziev, Banabakova, Georgiev, 2018g, pp. 935-944; Terziev, Banabakova, Georgiev, pp. 973-980; Terziev, Banabakova, Georgiev, 2018i, pp. 1275-1281; Terziev, Georgiev, 2018j, pp. 6-15; Terziev, Banabakova, Georgiev, 2018k, s.93-98; Terziev, Banabakova, Georgiev, 2018I, s. 99-104; Terziev, Banabakova, Georgiev, 2018m, s. 104-109; Terziev, Banabakova, Georgiev, 2018n, s. 110-115; Terziev, Banabakova, Georgiev, 2018o, s. 116-121; Terziev, Banabakova, Georgiev, 2018p, s. 122-127; Terziev, Banabakova, Georgiev, 2018q, s. 127-131; Terziev, Banabakova, Georgiev, 2018r, s. 132-137; Terziev, Banabakova, Georgiev, 2018s, s. 137-142; Terziev, 2017a, pp.505-516).

The methodology for the development of an active social program, shown in Fig. 1 requires the focus on the following theoretical components:

The ascertainment of the social problem;

The determination of the social objective of the program as a starting point for programming of the process for development of human resources. The external social environment provides an objective characteristic of the surrounding conditions, parameters and structure of the external objects that interact in one way or another with the given object;

The projection of the planned trajectory for the development of human resources, which takes place within 
and under the reporting of the adopted for implementation comprehensive set of national and regional programs in accordance with the pre-determined social criteria.

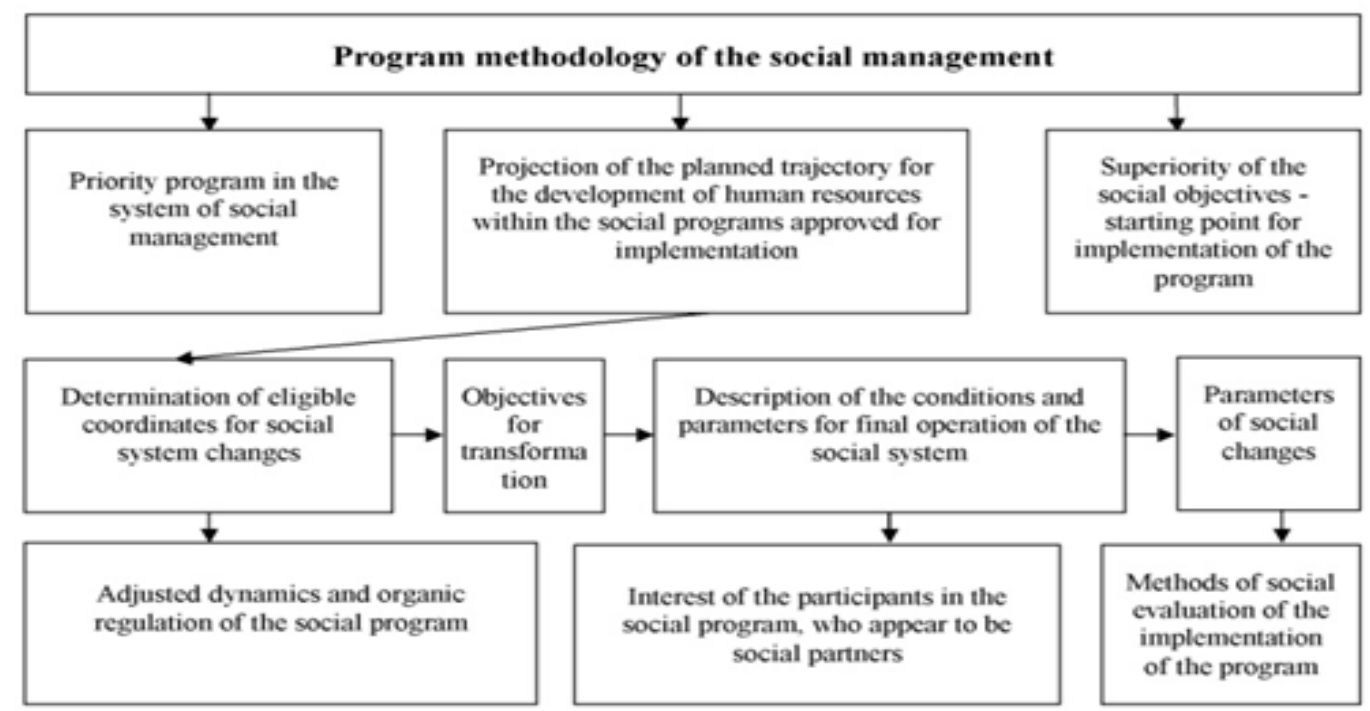

Fig. 1. Methodology for the development of an active social program

It is noteworthy that the projection of the trajectory of development of human resources is related to the determination of eligible coordinates for changes of the social system. More specifically, it should solve the following objective tasks: first, determining the initial coordinates of the process of development of human resources; second, a description of the terms and conditions of its final states (final coordinates of the trajectory of motion); third, setting the criteria for qualitative and quantitative indicators for human resources development. That means to bind the objective with the final targeted state, which lies essentially in the basis of the management by results.

We should take into account that the most important goal of the modern social programs is determined by the faster level of knowledge, prediction and reaching of socially significant consequences for the future in shaping the overall educational process. Achieving a certain goal may serve as a criterion in the implementation of the model for a proactive education as a basis of the social construction of the faster human development. By its nature, the given social construction is a synthesis of the implementation of a complex of active social programs of society.

In the search of optimal forms of social construction, the central axis is a dynamically developing education system and the corresponding new type of dynamically developing intelligence, a new personality. This position can be argued by the fact that the education system is a social industry, which prepares specialists with one type of thinking or another. In other words, this is the spiritual targeted development of a certain type of personality, which in its essence is a system of expanded reproduction of the spiritual culture of the members of a given society. Society is transformed and developed rapidly and the system of educational institutions, educational practice is a "bottleneck" for this process. The practice shows that educational institutions of different rank demonstrate quantitative growth of graduate specialists, without taking caring about the conformity of their qualities with the growing needs of modern social development. And in order to overcome this inconsistency, the creation of conditions for competition of the structural elements of the education system is necessary. The educational development of human resources, determining the set of the acquired systematic knowledge, skills and professional habits, as well as the acquired skills for further learning and analysis of knowledge, exchange and use of information in the process of professional activity, are namely the most important factor and the social objective of the whole social policy adequate to the requirements of the labor market and the economy based on knowledge.

The active social program also features the dynamic adjustment regulation by using the feedback in its implementation. The functions of the adjustment regulator are a kind of solution of the problem of optimization of its components as a result of the changes in the conditions of life activity of the population damping down of the external disturbing social impulses, arising in the implementation of the social program.

The adjustment regulator of the program consists in turn of three interrelated parts: the systems for social studies, the organic system for planning and the organic regulatory system. The system of social studies is implemented by the methods that study the social interests of the population. As a result of the social studies, the needs and preferences of the population by certain social benefits are revealed. Among them 
are housing, healthcare, sport and cultural needs, retraining and rehabilitation training of the staff. Social planning is implemented with the aim of solving a social problem caused by the incompatibility of the components of the social program with the changed requirements.

The process of creating conditions for active implementation of the social program, gives an idea of social regulation. The successful implementation of the social regulation contributes to unification of the program participants, to bringing their interests and the interests of the public layers to which the program is directed, closer.

The given components are completely identical in their structure and consist of the following interrelated parts: predicting (anticipatory reflection of reality); planning of social changes in the components of the system; simulation model for the formation of the process of implementation of the program; internal immediate adapter of the system for program management, external adapter of the program management system; internal adapter of the system for program management.

The principle of anticipatory reflection of reality expresses the possibility of adaptation of society to changing environmental conditions and the very possibility of existence, the ability to raise awareness of the current and future reality. The anticipatory reflection of the social reality is one of the forms to reflect future social development, which is a "historical foundation for the emergence of all higher forms of anticipating future events and above all the emergence of conditioned reflex".

The principle of anticipatory reflection of reality in the social program is expressed in the reporting of determination of the future performance of project impact: social prediction, social anticipation, social projection, social programming, social planning, social construction, social engineering. Based on the principle of anticipatory reflection of social reality, ,in this dimension the principle of anticipatory reflection of social reality as a fundamental principle of social projection can be formulated".

Under the new conditions, the theoretical paradigm of social programs requires a synthesis of the theory of active systems that objectively to lead to the provision of conditions and motivational activity among the participants of the target social program. It is namely the activity of the element of the system that corresponds to a greater extent to the model for active target social program, the implementation of which is through the involvement of independent participants: the population, the government and public social institutions, as shown in Fig. 2.

The development of an active target social program implies the presence of four components of the mechanism for its activation, which can be seen in Fig. 3.

The participants in the program, who have a wide range of choice of action aiming at implementation of their interests, are the first component. This means that each participant in the social program is interested in solving a topical for them social task on the account of their participation in it.

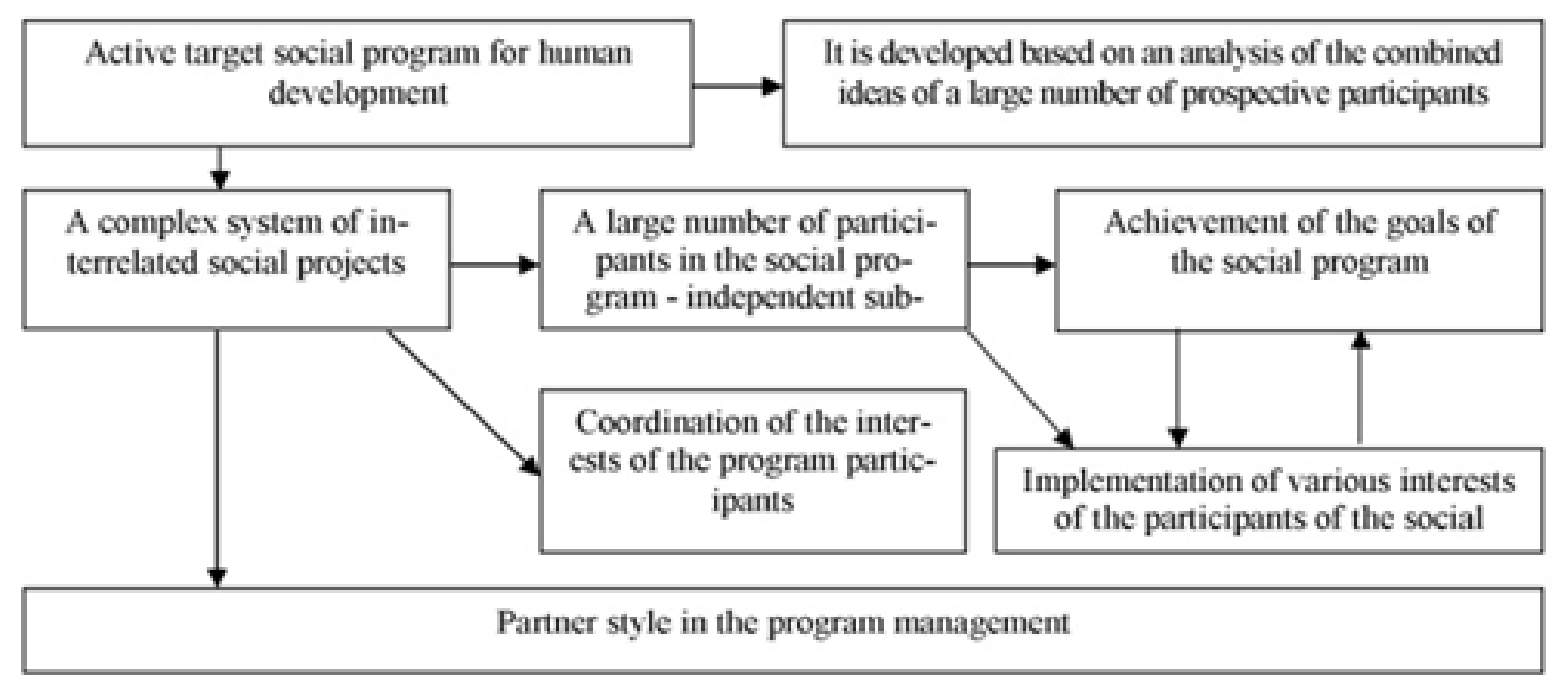

Fig. 2. Specifics of the active social program for human development. 


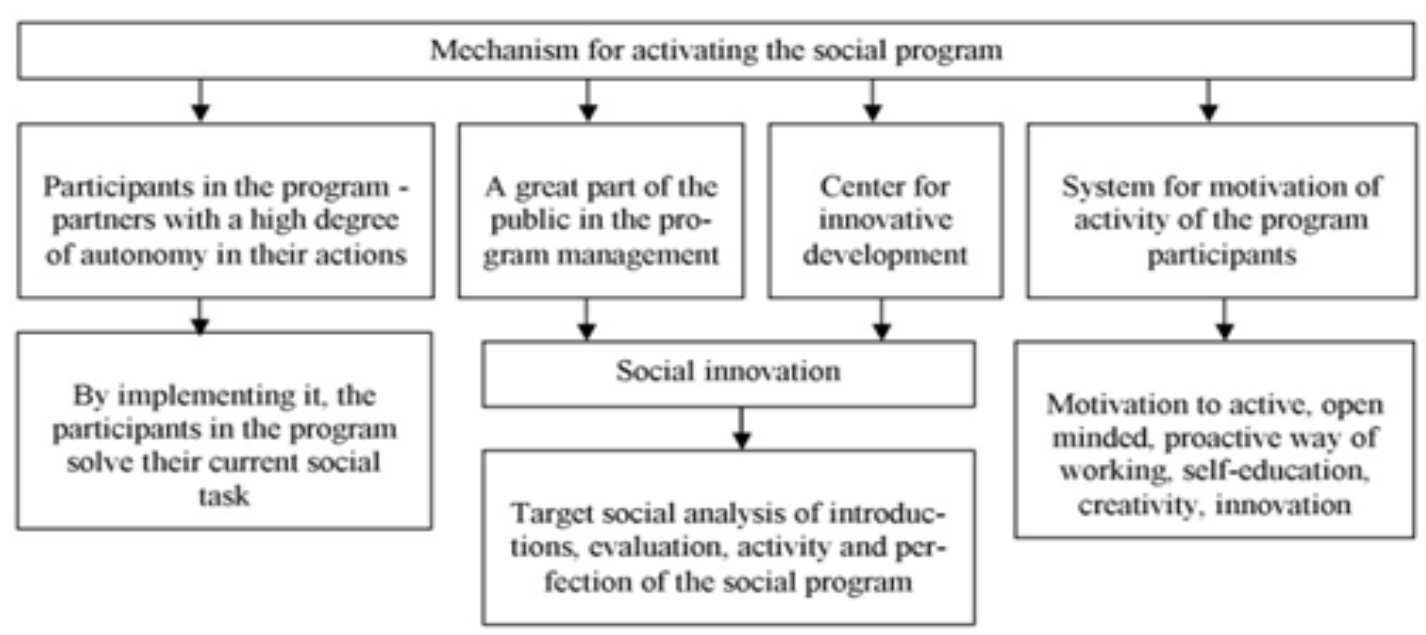

Fig. 3. Components of the mechanism for activation of the social program.

The second component is the presence of a body with broad composition of managers of the social program and broad involvement of the public. The body shall not only examine the social results of the implementation, collect data, assess the stages of implementation of the program as a whole, but also develop guidelines for correction of the program elements.

The third component is defined by the system of motivation of a large composition of participants in the program. The development and implementation of the social program requires a special form of motivation of an open minded, active, scientific style of work that determines self-education, creativity and innovation development in any job.

The fourth component is expressed in the need for permanent operating innovation center for innovative improvement of the social program, for activation of the processes of its renewal.

It is noteworthy that the highly qualified intellectual labor is combining between these four components of the mechanism for activating the social program. It is the potential of opportunity for self-improvement of the social program. The self-growing resource that has a cultural value and determines the potential for an active adaptation to the changing social environment, gives an idea of scientific innovation activity of the program participants. In other words, this is the resource of knowledge, which ranks today together with other resources (financial, material, human, information), which are subject to transformation into specific capabilities. Thus, the active social programs are aimed at solving social problems through implementation of breakthrough, innovative social technologies, attraction of investments, optimization of social resource flows, integration of social systems. The development of the social program denies the principle of ending the ongoing social measures. Each active social project is above all an innovation project, as its main objective consists in the development and use of new ideas that might be new social technologies aimed at providing social services that lead to dynamic social development and the viability of the population.

The active social program is created as a complex of social projects based on the common idea of social interaction, ensuring the coordination of the interests of the population in conditions of unstable social environment impact. The active social program is a systematic development. Each integral part of the active social program, considered separately, is interconnected and interdependent with its other parts. As a rule, in the self-realization of the individual elements of the social program, separated from one another, conditions for a sharp reduction of the effectiveness of its implementation are created.

The optimal synthesis of thoughts, ideas and objectives of the program participants, the composition of which also includes representatives of the public, is the so-called common social idea of the active program. Moreover, the participants in the social program are relatively independent, act on the basis of their own interests - every participant within the framework of their participation in the social program determines their own interest. The program is developed on the basis of the creation of a common socially significant idea, in order to coordinate personal interests with the objective of the active program. The social program is developed based on the study of ideas and innovative thinking of the participants, on the basis of a comprehensive analysis in the field of implementation of the active social project through the formation of a common idea and development of schemes for the interests of the participants and the public. Based on the already obtained data, the structure of the active social program is formed, a network of organizations with the program participants is created around the representative of the common social idea, who assumes the role of coordinator and supervisor of the program implementation. 
The active social programs have a number of common features. They include: a focus on achieving specific objectives; coordinated implementation of interrelated actions; limited in time action with a determined beginning and a period for development of a new program or its completion; originality and uniqueness to a certain extent.

The result of the active social programming allows the implementation of the comprehensive program with a maximum efficiency under the conditions of a dynamically changing social environment. Moreover, based on the common ideas, the involvement of relatively independent functioning social institutions is ensured by coordinating their needs and interests. The active approach is primarily directed to reaching an effective development of the social object of the program by implementation of breakthrough innovation technologies, attracting to public management, optimization of the resource flows, integration of the social systems of the program participants. The term „active programming” emphasizes the continuous process of adaptation of the developed program to the conditions of the social environment of the system. Therefore, the active social program is open to self-development of the system. The success of its management implementation is largely determined by the factors of interaction of the elements of the social program with the constantly changing environment of its impact. Unlike the conventional social programs, its active form represents a creative self-developing project with a transformable final social goal, means and tasks of the process of social changes, which denies the fixed static schemes of classic social programming. The active social programs are directed to local social stabilization in unstable dynamically developing conditions of the environmental for social impact. The active projection is mainly directed towards the effective development of the social objects on the way to deployment of innovations; optimization of financial, resource and innovation flows; integration of socio-economic projects in global economic relations.

Information, as a result of the social study on the conditions for implementation of the program, is the basis for the establishment of all relevant systematically interrelated factors for social changes, reflecting the nature of the ongoing processes and phenomena. The participants in the active social program also have and implement skills for active creative conduct, related not only to the development and organization of the implementation of the social program, but with the ability to accumulate and reasonable adopt different kind of innovations as well. The implementation of the social program largely depends on the professionalism of its implementation. Nowadays, the main criterion for the quality of the program is the professionalism of its participants. These are the national and European employment services, whose coordination guarantees the effectiveness of one social program or another and the social policy of a country. This is the reason for the development of a common strategy for the future, approved by all European public employment services, subject to our further studies.

\section{CONCLUSION}

The modern application of the programming as a general principle of management, is associated with preliminary planned future actions and activities aimed at achieving a certain goal with certain means, in accordance with the challenges of the dynamic changes, resulting from the changes in the social environment based on alternativeness of the decisions and the optimal choice, contributing to the effective management. The concretization of the management objectives achieved through the social program as a structured dynamic image and a way of action for coordinated interaction between the bodies of power allows the solution of important social problems, in accordance with the specific conditions, changing circumstances and stated public interests.

The development and the achieved efficiency is perceived as a multi-layered expedient process, covering identification, analysis and operational fulfillment of the established social needs on the one hand, and as an opportunity to consolidate the efforts of the institutionally stated publicly significant subjects, on the other. The established conditions and the critical analysis place the focus of attention on social programming and specifically determine the finding of a relevant methodology for the engagement of any social agenda with a concrete result perceived as a success and finding a way to effectively control and measure every success. The creation of an objective assessment of this specific efficiency challenges the science of management to turn every established social program regarded as "good practice" into a standard for efficient work.

The analysis on the nature of the social policy confirms that human resources in their purposeful activity achieve goals, influencing the other resources and other factors of the social environment transforming them into human capital. The development of this process gives the opportunity this specific mechanism of change to be interpreted as a social system with high public activity, which predetermines the improvement of public relations. Within their structure, creativity stands out, presenting the role of the individual, reproducing a certain social experience for enriching the social relations and making an application for participation in the labor process (Dimitrova, Georgiev 2017b, s. 204-235; Dimitrova, Georgiev, 2017c, s. 235-258; Terziev, Georgiev, 2017d, pp. 1418-1437; Terziev, Georgiev, 2017e, pp. 24-31; Terziev, Georgiev, 2017f, pp. 32-34; 
Georgiev, 2017g, pp. 139-143; Terziev, Banabakova, Georgiev, 2017h, s.64-69; Terziev, Banabakova, Georgiev, 2017i, s.70-75; Terziev, Banabakova, Georgiev, 2017j, s.76-81; Terziev, Banabakova, Georgiev, 2017k; s. 103-106; Terziev, Banabakova, Georgiev, 2017l, s. 100-103; Terziev, Banabakova, Georgiev, 2017m, s. 97-100; Terziev, Banabakova, Latyshev, Georgiev, 2017n, pp. 773-791; Terziev, Nichev, Stoyanov, Georgiev, 2017o, pp. 707-710; Terziev, Nichev, Stoyanov, Georgiev, Bogdanov, 2017p, pp. 701706; Terziev, Nichev, Stoyanov, Georgiev, 2017q, pp. 695-700; Terziev, Nichev, Stoyanov, Georgiev, 2017r, pp. 690-694; Terziev, Latyshev, Georgiev, 2017s, pp.754-772; Terziev, Latyshev, Georgiev, 2017t, pp. 638659; Terziev, Nichev, Stoyanov, Georgiev, 2017u, pp. 888-892; Terziev, Nichev, Stoyanov, Georgiev, 2017v, pp. 893-898; Terziev, Nichev, Stoyanov, Georgiev, Bogdanov, 2017w, pp. 903-908; Terziev, Nichev, Stoyanov, Georgiev, 2017x, pp. 909-912; Terziev, Banabakova, Latyshev, O., Georgiev, 2017y, pp. 10561074).

\section{REFERENCE LIST}

Terziev, Venelin. (2017). Politiki i instrumenti za sotsialno razvitie, Innovations and Sustainability Academy, 2017, ISBN 978-619-7246-14-8, 318 str. (Terziev, Venelin. Политики и инструменти за социално развитие, Innovations and Sustainability Academy, 2017, ISBN 978-619-7246-14-8, 318 стр.).

Terziev, V., E. Arabska, (2016). Effektivnoe vliyanie na raynok truda posredstvom uluchsheniya realizatsii sotsialynoy politiki. Novosibirsk: Izdatelystvo TSRNS, 2016. ISBN 978-5-00068-496-2, 312 str. (Терзиев, В., Е. Арабска, Эфрфективное влияние на рынок труда посредством улучшения реализации социальной политики. Новосибирск: Издательство ЦРНС, 2016. ISBN 978-5-00068496-2, 312 стр).

Terziev, Venelin. (2018). Sotsialno razvitie- politiki i instrumenti, Nauchen institut za menaџment i znaeњe, Skopje, 2018, ISBN 978-608-4834-02-1, 307 р. (Терзиев, Венелин. Социално развитие- политики и инструменти, Научен институт за менаџмент и знаење, Скопје, 2018, ISBN 978-608-4834-02-1, 307 p).

Terziev, Venelin. (2015). Assessment of active social policies impact of social policies on transformation processes in Bulgarian economy, Moscow, 2015, Publisher „Перо“, 110 p. (Publisher „Pero“).

Terziev, Venelin. (2015a). Impact of active social policies and programs in the period of active economic transformations in Bulgaria, „East West” Association for Advanced Studies and Higher Education, Vienna, 2015, ISBN 78-3-903063-44-0, 434 p.

Terziev, V., E. Arabska. (2015b). Theoretical and methodological basis of social programming and social activity, Kolektivnaya monografiya 2015, Ufa, Aeterna. Rossiya.ISBN 978-5-906808-20-2, 198 p. (Terziev, V., E. Arabska, Theoretical and methodological basis of social programming and social activity, Колективная монографиия 2015, Уфра, Аэтерна. Россия.ISBN 978-5-906808-20-2, 198 р).

Terziev, V., E. Arabska. (2015c). Organic production and management in the Republic of Bulgaria contributing to sustainable development and assurance of safe and healthy living environment, Kolektivnaya monografiya, 2015, Ufa, Aeterna. Rossiya. (monografiya). ISBN 978-906781-40-6 (Terziev, V., E. Arabska, Organic production and management in the Republic of Bulgaria contributing to sustainable development and assurance of safe and healthy living environment, Колективная монография, 2015, Уфра, Аэтерна. Россия. (монография). ISBN 978-906781-40-6).

Terziev, V., E. Arabska. (2014). Assessment of active social policies' impacts on labor market in the Republic of Bulgaria. Kolektivnaya monografiya "Sotsialyno-ekonomicheskie i pravovay razvitiya ekonomiki“, Ufa, Aeterna. Rossiya, 2014. Retsenzetay: Shaybakov R.N., d.e.n., prof, Yangirov A.V. d.e.n., prof. ISBN 978-5-906769-97-8, str. 3-57 (Terziev, V., E. Arabska. Assessment of active social policies' impacts on labor market in the Republic of Bulgaria. Колективная монографрия „Социальноэкономические и правовы развития экономики“, Уфа, Аэтерна. Россия, 2014. Рецензеты: Шайбаков Р.Н., д.э.н., проф, Янгиров А.В. д.э.н., проф. ISBN 978-5-906769-97-8, стр. 3-57).

Terziev, Venelin. (2015d). Analyses of Labor Market Development in the Republic of Bulgaria and the influence of the transition period, TSRNS, Novosibirsk, Rossiya, 30.04.2015 (Terziev, Venelin. Analyses of Labor Market Development in the Republic of Bulgaria and the influence of the transition period, ЦРНС, Новосибирск, Россия, 30.04.2015).

Terziev, V., Georgiev, M. (2018a). Sotsialna zashtita na uyazvimite grupi ot naselenieto v Balgariya. // 
Sbornik dokladi ot godishna universitetska nauchna konferentsiya 14-15 yuni 2018 g., Elektronno izdanie, NVU Vasil Levski- Veliko Tarnovo, Veliko Tarnovo, 2018, str. 970-975, ISBN 978-619-724620-9 (online e-book), ISSN 2367-7481 (Терзиев, В., Георгиев, М. Социална защита на уязвимите групи от населението в България. // Сборник доклади от годишна университетска научна конфреренция 14-15 юни 2018 г., Електронно издание, НВУ Васил Левски- Велико Търново, Велико Търново, 2018, стр. 970-975, ISBN 978-619-7246-20-9 (online e-book), ISSN 2367-7481).

Terziev, V., Georgiev, M. (2018b). Harakteristiki na sistemata za sotsialno podpomagane. // Sbornik dokladi ot godishna universitetska nauchna konferentsiya 14-15 yuni 2018 g., Elektronno izdanie, NVU Vasil Levski- Veliko Tarnovo, Veliko Tarnovo, 2018, str. 959-969, ISBN 978-619-7246-20-9 (online e-book), ISSN 2367-7481 (Терзиев, В., Георгиев, М. Характеристики на системата за социално подпомагане. // Сборник доклади от годишна университетска научна конференция 14-15 юни 2018 г., Електронно издание, НВУ Васил Левски- Велико Търново, Велико Търново, 2018, стр. 959-969, ISBN 978-619-7246-20-9 (online e-book), ISSN 2367-7481).

Terziev, V., Georgiev, M. (2018c). Podhodi pri obuchenie v organizatsiyata. // Sbor-nik dokladi ot godishna universitetska nauchna konferentsiya 14-15 yuni 2018 g., Elek-tronno izdanie, NVU Vasil LevskiVeliko Tarnovo, Veliko Tarnovo, 2018, str. 951-958, ISBN 978-619-7246-20-9 (online e-book), ISSN 2367-7481 (Терзиев, В., Георгиев, М. Подходи при обучение в организацията. // Сбор-ник доклади от годишна университетска научна конференция 14-15 юни 2018 г., Елек-тронно издание, НВУ Васил Левски- Велико Търново, Велико Търново, 2018, стр. 951-958, ISBN 978619-7246-20-9 (online e-book), ISSN 2367-7481).

Terziev, V., Georgiev, M. (2018d). Sotsialna zashtita na uyazvimite grupi ot naselenieto v Balgariya. // Sbornik dokladi ot Godishna universitetska nauchna konferentsiya 14-15 yuni 2018g., Nauchno napravlenie „Sotsialni, stopanski i pravni nauki”, NVU Veliko Tarnovo, Veliko Tarnovo, Izdatelski kompleks na NVU „Vasil Levski”, 7, 2018, str. 188-193, ISBN 978-619-7246-20-9 (online e-book), ISSN 1314-1937 (Терзиев, В., Георгиев, М. Социална защита на уязвимите групи от населението в България. // Сборник доклади от Годишна университетска научна конференция 14-15 юни 2018г., Научно направление „Социални, стопански и правни науки”, НВУ Велико Търново, Велико Търново, Издателски комплекс на НВУ „Васил Левски”, 7, 2018, стр. 188-193, ISBN $978-$ 619-7246-20-9 (online e-book), ISSN 1314-1937).

Terziev, V., Georgiev, M. (2018e). Harakteristiki na sistemata za sotsialno podpomagane. // Sbornik dokladi ot Godishna universitetska nauchna konferentsiya 14-15 yuni 2018g., Nauchno napravlenie „Sotsialni, stopanski i pravni nauki”, NVU Veliko Tarnovo, Veliko Tarnovo, Izdatelski kompleks na NVU „Vasil Levski”, 7, 2018, str. 177-187, ISBN 978-619-7246-20-9 (online e-book), ISSN 1314-1937 (Терзиев, В., Георгиев, М. Характеристики на системата за социално подпомагане. // Сборник доклади от Годишна университетска научна конференция 14-15 юни 2018г., Научно направление „Социални, стопански и правни науки”, НВУ Велико Търново, Велико Търново, Издателски комплекс на НВУ „Васил Левски”, 7, 2018, стр. 177-187, ISBN 978-619-7246-20-9 (online e-book), ISSN 1314-1937).

Terziev, V., Georgiev, M. (2018f). Podhodi pri obuchenie v organizatsiyata. // Sbornik dokladi ot Godishna universitetska nauchna konferentsiya 14-15 yuni 2018g., Nauchno napravlenie „Sotsialni, stopanski i pravni nauki”, NVU Veliko Tarnovo, Veliko Tarnovo, Izdatelski kompleks na NVU „Vasil Levski”, 7, 2018, str. 169-176, ISBN 978-619-7246-20-9 (online e-book), ISSN 1314-1937 (Терзиев, B., Георгиев, М. Подходи при обучение в организацията. // Сборник доклади от Годишна университетска научна конфреренция 14-15 юни 2018г., Научно направление „Социални, стопански и правни науки", НВУ Велико Търново, Велико Търново, Издателски комплекс на НВУ „Васил Левски”, 7, 2018, стр. 169-176, ISBN 978-619-7246-20-9 (online e-book), ISSN 1314-1937).

Terziev, V., Banabakova, V., Georgiev, M. (2018g). Modern dimensions of social policies. // International journal scientific papers Vol 23.4 Promoted in Budva, Montenegro 24-27.05.2018, IKM - Skopje, 23, 2017, N 4, pp. 935-944, ISSN 1857-923X (for e-version) ISSN 2545- 4439 (for printed version).

Terziev, V., Banabakova, V., Georgiev, M. (2018h). Social support as part of social policy. // International journal scientific papers Vol 23.4 Promoted in Budva, Montenegro 24-27.05.2018, IKM - Skopje, 23, 2017, N 4, pp. 973-980, ISSN 1857-923X (for e-version) ISSN 2545 - 4439 (for printed version).

Terziev, V., Banabakova, V., Georgiev, M. (2018i). Structure of the social welfare system in Bulgaria. // International journal scientific papers Vol 23.4 Promoted in Budva, Montenegro 24-27.05.2018, IKM Skopje, 23, 2017, N 4, pp. 1275-1281, ISSN 1857-923X (for e-version) ISSN 2545 - 4439 (for printed version). 
IJASOS- International E-Journal of Advances in Social Sciences, Vol. IV, Issue 12, December 2018

Terziev, V., Georgiev, M. (2018j). Efficient management as optimization of the organization. // IJAEDUInternational E-Journal of Advances in Education, April 2018, International Organization Center of Academic Research, www.ocerints.org, Istanbul, Turkey, 2018, pp. 6-15, 4, 2018, N 10, e-ISSN: 2411 183X.

Terziev, V., Banabakova, V., Georgiev, M. (2018k). Role and place of social programing in public governance. // Mizhnarodnoï naukovo-praktichnoï konferentsiï «Zabezpechennya stalogo rozvitku ekonomiki: problemi, mozhlivosti, perspektivi» (16-17 lyutogo 2018 roku, m. Uzhgorod), Ministerstvo osviti i nauki Ukraïni Uzhgorodsykiy natsionalyniy universitet, 2018, s.93-98, ISBN 978-966-916-488-9 (Terziev, V., Banabakova, V., Georgiev, M. Role and place of social programing in public governance. // Міжнародної науково-практичної конфреренції «Забезпечення сталого розвитку економіки: проблеми, можливості, перспективи» (16-17 лютого 2018 року, м. Ужгород), Міністерство освіти і науки України Ужгородський національний університет, 2018, с.93-98, ISBN 978-966-916-488-9).

Terziev, V., Banabakova, V., Georgiev, M. (2018I). Social program as a product of social programming. // Mizhnarodnoï naukovo-praktichnoï konferentsiï «Zabezpechennya stalogo rozvitku ekonomiki: problemi, mozhlivosti, perspektivi» (16-17 lyutogo 2018 roku, m. Uzhgorod), Ministerstvo osviti i nauki Ukraïni Uzhgorodsykiy natsionalyniy universitet, 2018, s. 99-104, ISBN 978-966-916-488-9 (Terziev, V., Banabakova, V., Georgiev, M. Social program as a product of social programming. // Міжнародної науково-практичної конфреренції «Забезпечення сталого розвитку економіки: проблеми, можливості, перспективи» (16-17 лютого 2018 року, м. Ужгород), Міністерство освіти і науки України Ужгородський національний університет, 2018, с. 99-104, ISBN 978-966-916-488-9).

Terziev, V., Banabakova, V., Georgiev, M. (2018m). Social efficiency as a measure of social activities. // Mizhnarodnoï naukovo-praktichnoï konferentsiï «Zabezpechennya stalogo rozvitku ekonomiki: problemi, mozhlivosti, perspektivi» (16-17 lyutogo 2018 roku, m. Uzhgorod), Ministerstvo osviti i nauki Ukraïni Uzhgorodsykiy natsionalyniy universitet, 2018, s. 104-109, ISBN 978-966-916-488-9 (Terziev, V., Banabakova, V., Georgiev, M. Social efficiency as a measure of social activities. // Міжнародної науково-практичної конфреренції «Забезпечення сталого розвитку економіки: проблеми, можливості, перспективи» (16-17 лютого 2018 року, м. Ужгород), Міністерство освіти і науки України Ужгородський національний університет, 2018, с. 104-109, ISBN 978-966-916-488-9).

Terziev, V., Banabakova, V., Georgiev, M. (2018n). Assessment of the effectiveness of social programing. // Mizhnarodnoï naukovo-praktichnoï konferentsiï «Zabezpechennya stalogo rozvitku ekonomiki: problemi, mozhlivosti, perspektivi» (16-17 lyutogo 2018 roku, m. Uzhgorod), Ministerstvo osviti i nauki Ukraïni Uzhgorodsykiy natsionalyniy universitet, 2018, s. 110-115, ISBN 978-966-916-488-9 (Terziev, V., Banabakova, V., Georgiev, M. Assessment of the effectiveness of social programing. // Міжнародної науково-практичної конфреренції «Забезпечення сталого розвитку економіки: проблеми, можливості, перспективи» (16-17 лютого 2018 року, м. Ужгород), Міністерство освіти і науки України Ужгородський національний університет, 2018, с. 110-115, ISBN 978-966-916-4889).

Terziev, V., Banabakova, V., Georgiev, M. (20180). Social activity of human resource as a basis of effective social policy. // Mizhnarodnoï naukovo-praktichnoï konferentsiï «Zabezpechennya stalogo rozvitku ekonomiki: problemi, mozhlivosti, perspektivi» (16-17 lyutogo 2018 roku, m. Uzhgorod), Ministerstvo osviti i nauki Ukraïni Uzhgorodsykiy natsionalyniy universitet, 2018, s. 116-121, ISBN 978-966-916488-9 (Terziev, V., Banabakova, V., Georgiev, M. Social activity of human resource as a basis of effective social policy. // Міжнародної науково-практичної конфреренції «Забезпечення сталого розвитку економіки: проблеми, можливості, перспективи» (16-17 лютого 2018 року, м. Ужгород), Міністерство освіти і науки України Ужгородський національний університет, 2018, с. 116-121, ISBN 978-966-916-488-9).

Terziev, V., Banabakova, V., Georgiev, M. (2018p). Strategic advantages of an active social program. // Mizhnarodnoï naukovo-praktichnoï konferentsiï «Zabezpechennya stalogo rozvitku ekonomiki: problemi, mozhlivosti, perspektivi» (16-17 lyutogo 2018 roku, m. Uzhgorod), Ministerstvo osviti i nauki Ukraïni Uzhgorodsykiy natsionalyniy universitet, 2018, s. 122-127, ISBN 978-966-916-488-9 (Terziev, V., Banabakova, V., Georgiev, M. Strategic advantages of an active social program. // Міжнародної науково-практичної конфреренції «Забезпечення сталого розвитку економіки: проблеми, можливості, перспективи» (16-17 лютого 2018 року, м. Ужгород), Міністерство освіти і науки України Ужгородський національний університет, 2018, с. 122-127, ISBN 978-966-916-488-9).

Terziev, V., Banabakova, V., Georgiev, M. (2018q). Assessment of the effectiveness of social programming. // Mizhnarodnoï naukovo-praktichnoï konferentsiï «Zabezpechennya stalogo rozvitku ekonomiki: 
problemi, mozhlivosti, perspektivi» (16-17 lyutogo 2018 roku, m. Uzhgorod), Ministerstvo osviti i nauki Ukraïni Uzhgorodsykiy natsionalyniy universitet, 2018, s. 127-131, ISBN 978-966-916-488-9 (Terziev, V., Banabakova, V., Georgiev, M. Assessment of the effectiveness of social programming. // Міжнародної науково-практичної конфреренції «Забезпечення сталого розвитку економіки: проблеми, можливості, перспективи» (16-17 лютого 2018 року, м. Ужгород), Міністерство освіти і науки України Ужгородський національний університет, 2018, с. 127-131, ISBN 978-966-916-4889).

Terziev, V., Banabakova, V., Georgiev, M. (2018r). The social program as a part of development strategies. // Mizhnarodnoï naukovo-praktichnoï konferentsiï «Zabezpechennya stalogo rozvitku ekonomiki: problemi, mozhlivosti, perspektivi» (16-17 lyutogo 2018 roku, m. Uzhgorod), Ministerstvo osviti i nauki Ukraïni Uzhgorodsykiy natsionalyniy universitet, 2018, s. 132-137, ISBN 978-966-916-488-9 (Terziev, V., Banabakova, V., Georgiev, M. The social program as a part of development strategies. // Міжнародної науково-практичної конференції «Забезпечення сталого розвитку економіки: проблеми, можливості, перспективи» (16-17 лютого 2018 року, м. Ужгород), Міністерство освіти і науки України Ужгородський національний університет, 2018, с. 132-137, ISBN 978-966-916-4889).

Terziev, V., Banabakova, V., Georgiev, M. (2018s). Social programming as a possibility to increase social efficiency. // Mizhnarodnoï naukovo-praktichnoï konferentsiï «Zabezpechennya stalogo rozvitku ekonomiki: problemi, mozhlivosti, perspektivi» (16-17 lyutogo 2018 roku, m. Uzhgorod), Ministerstvo osviti i nauki Ukraïni Uzhgorodsykiy natsionalyniy universitet, 2018, s. 137-142, ISBN 978-966-916488-9 (Terziev, V., Banabakova, V., Georgiev, M. Social programming as a possibility to increase social efficiency. // Міжнародної науково-практичної конференції «Забезпечення сталого розвитку економіки: проблеми, можливості, перспективи» (16-17 лютого 2018 року, м. Ужгород), Міністерство освіти і науки України Ужгородський національний університет, 2018, с. 137-142, ISBN 978-966-916-488-9).

Terziev, Venelin. (2017a). Modeling active social programs in Bulgaria through social entrepreneurship encouragement. // 3rd Central \& Eastern European LUMEN International Conference, New Approaches in Social and Humanistic Sciences NASHS 2017, Chisinau, Republic of Moldova, June 8-10, 2017, 2018, pp.505-516, ISSN (print): 2601 - 2510, ISSN (on-line): 2601 - 2529, ISSN-L: 2601 - 2510, ISBN: 978-1-910129-15-9.

Dimitrova, P., Georgiev, M. (2017b). Model of methodology for determining the needs of continuing vocationaltraining work specialists providing social services. // Innovatsii, tehnologii, nauka. Sbornik statey Mezhdunarodnoy nauchno - prakticheskoy konferentsii 25 yanvarya 2017 g., NITS Aeterna Permy, Chasty 4, 2017, s. 204-235, ISBN 978-5-906925-99-2, ISBN 978-5-00109-000-7 (Dimitrova, P., Georgiev M. Model of methodology for determining the needs of continuing vocationaltraining work specialists providing social services. // Инновации, технологии, наука. Сборник статей Международной научно - практической конференции 25 января 2017 г., НИЦ Аэтерна Пермь, Часть 4, 2017, с. 204-235, ISBN 978-5-906925-99-2, ISBN 978-5-00109-000-7).

Dimitrova, P., Georgiev, M. (2017c). Research, identification and monitoring of the needs of occupational training of social activities experts. // Innovatsii, tehnologii, nauka. Sbornik statey Mezhdunarodnoy nauchno - prakticheskoy konferentsii 25 yanvarya 2017 g., NITS Aeterna Permy, Chasty 4, 2017, s. 235-258, ISBN 978-5-906925-99-2, ISBN 978-5-00109-000-7 (Dimitrova, P., Georgiev M. Research, identification and monitoring of the needs of occupational training of social activities experts. // Инновации, технологии, наука. Сборник статей Международной научно - практической конфреренции 25 января 2017 г., НИЦ Аэтерна Пермь, Часть 4, 2017, с. 235-258, ISBN 978-5906925-99-2, ISBN 978-5-00109-000-7).

Terziev, V., Georgiev, M. (2017d). The active model of a social programme and ITS strategic advantage. // Medical Teacher. Taylor \& Francis, 39, 2017, N 12 (2), pp. 1418-1437, ISSN: 0142-159X (Print), ISSN: 1466-187X (Online).

Terziev, V., Georgiev, M. (2017e). Impact of the labor market policies for ensuring em-ployment. // Proceedings of Academics World 57th International Conference, Paris, France, 13th -14th February 2017, 2017, pp. 24-31, ISBN: 978-93-86083-34-0.

Terziev, V., Georgiev, M. (2017f). Importance of human resources to social development. // Proceedings of Academics World 57th International Conference, Paris, France, 13th -14th February 2017, 2017, pp. 32-34, ISBN: 978-93-86083-34-0. 
IJASOS- International E-Journal of Advances in Social Sciences, Vol. IV, Issue 12, December 2018

Georgiev, Marin. (2017g). Impacts of active social programs on labor market. // Mezhdunarodnayy nauchnayy zhurnal «Innovatsionnaya nauka». NITS Aeterna, N 02-1, 2017, pp. 139-143 (Georgiev, Marin. Impacts of active social programs on labor market. // Международный научный журнал «Инновационная наука». НИЦ Аэтерна, N 02-1, 2017, рр. 139-143).

Terziev, V., Banabakova, V., Georgiev, M. (2017h). Razvitie i perestrukturirovanie zanyatosti v Bolgarii s nachala perehoda k raynochnoy ekonomike i v goday evropeyskoy integratsii. // Gromadsyka organizatsiya «Kiïvsykiy ekonomichniy naukoviy tsentr» Zbirnik materialiv vseukraïnsykoï naukovopraktichnoï konferentsiï «Pidpriemnitstvo, buhgaltersykiy oblik ta finansi: natsionalyni osoblivosti ta svitovi tendentsiï» 15-16 veresnya 2017 roku, Kiïv 2017, s.64-69 (Терзиев. В, Банабакова. В., Георгиев, М. Развитие и переструктурирование занятости в Болгарии с начала перехода к рыночной экономике и в годы европейской интеграции. // Громадська організація «Київський економічний науковий центр» Збірник матеріалів всеукраїнської науково-практичної конференції «Підприємництво, бухгалтерський облік та фінанси: національні особливості та світові тенденції» 15-16 вересня 2017 року, Київ 2017, с.64-69).

Terziev, V., Banabakova, V., Georgiev, M. (2017i). Razvitie i perestrukturirovanie zanyatosti v Bolgarii. // Gromadsyka organizatsiya «Kiïvsykiy ekonomichniy naukoviy tsentr» Zbirnik materialiv vseukraïnsykoï naukovo-praktichnoï konferentsiï «Pidpriemnitstvo, buhgaltersykiy oblik ta finansi: natsionalyni osoblivosti ta svitovi tendentsiï» 15-16 veresnya 2017 roku, Kiïv 2017, s.70-75 (Терзиев. B, Банабакова. В., Георгиев, М. Развитие и переструктурирование занятости в Болгарии. // Громадська організація «Київський економічний науковий центр» Збірник матеріалів всеукраїнської науково-практичної конференції «Підприємництво, бухгалтерський облік та фрінанси: національні особливості та світові тенденції» 15-16 вересня 2017 року, Київ 2017, с.7075).

Terziev, V., Banabakova, V., Georgiev, M. (2017j). Politiki dlya vozdeystviya i analiz sostoyaniya na raynok truda. // Gromadsyka organizatsiya «Kiïvsykiy ekonomichniy naukoviy tsentr» Zbirnik materialiv vseukraïnsykoï naukovo-praktichnoï konferentsiï «Pidpriemnitstvo, buhgaltersykiy oblik ta finansi: natsionalyni osoblivosti ta svitovi tendentsiï» 15-16 veresnya 2017 roku, Kiïv 2017, s.76-81 (Терзиев. В, Банабакова. В., Георгиев, М. Политики для воздействия и анализ состояния на рынок труда. // Громадська організація «Київський економічний науковий центр» Збірник матеріалів всеукраїнської науково-практичної конфреренції «Підприємництво, бухгалтерський облік та фінанси: національні особливості та світові тенденції» 15-16 вересня 2017 року, Київ 2017. с.7681).

Terziev, V., Banabakova, V., Georgiev, M. (2017k). Razvitie kontseptsii sotsialynoy ekonomiki. // Materiali dopovidey mizhnarodnoï naukovo - praktichnoï konferentsiï «Suchasni mozhlivosti zabezpechennya sotsialyno-ekonomichnogo rozvitku kraïn» 16 veresnya 2017 roku, Ministerstvo osviti i nauki Ukraïni, Uzhgorodsykiy natsionalyniy universitet, Fakulytet mizhnarodnih ekonomichnih vidnosin,

Ekonomichniy fakulytet, Institut derzhavnogo upravlinnya ta regionalynogo rozvitku, Uzhgorod, 2017, s. 103-106, ISBN 978-966-916-348-6 (Терзиев. В, Банабакова. В., Георгиев, М. Развитие концепции социальной экономики. // Матеріали доповідей міжнародної науково - практичної конфреренції «Сучасні можливості забезпечення соціально-економічного розвитку країн» 16 вересня 2017 року, Міністерство освіти і науки України, Ужгородський національний університет, Факультет міжнародних економічних відносин, Економічний факультет, Інститут державного управління та регіонального розвитку, Ужгород, 2017, с. 103-106, ISBN 978-966-916-348-6).

Terziev, V., Banabakova, V., Georgiev, M. (2017l). Osobennosti, institutsii i znachenie razvitiya raynka truda. Materiali dopovidey mizhnarodnoï naukovo - praktichnoï konferentsiï «Suchasni mozhlivosti zabezpechennya sotsialyno-ekonomichnogo rozvitku kraïn» 16 veresnya 2017 roku, Ministerstvo osviti i nauki Ukraïni, Uzhgorodsykiy natsionalyniy universitet, Fakulytet mizhnarodnih ekonomichnih vidnosin, Ekonomichniy fakulytet, Institut derzhavnogo upravlinnya ta regionalynogo rozvitku, Uzhgorod, 2017, s. 100-103, ISBN 978-966-916-348-6 (Терзиев. В, Банабакова. В., Георгиев, М. Особенности, институции и значение развития рынка труда. Матеріали доповідей міжнародної науково - практичної конференції «Сучасні можливості забезпечення соціально-економічного розвитку країн» 16 вересня 2017 року, Міністерство освіти і науки України, Ужгородський національний університет, Факультет міжнародних економічних відносин, Економічний факультет, Інститут державного управління та регіонального розвитку, Ужгород, 2017, с. 100103, ISBN 978-966-916-348-6).

Terziev, V., Banabakova, V., Georgiev, M. (2017m). Osobennosti, institutsii i znachenie razvitiya raynka truda dlya dostizheniya ustoychivogo ekonomicheskogo i sotsialynogo razvitiya. // Materiali dopovidey 
mizhnarodnoï naukovo - praktichnoï konferentsiï «Suchasni mozhlivosti zabezpechennya sotsialynoekonomichnogo rozvitku kraïn» 16 veresnya 2017 roku, Ministerstvo osviti i nauki Ukraïni, Uzhgorodsykiy natsionalyniy universitet, Fakulytet mizhnarodnih ekonomichnih vidnosin, Ekonomichniy fakulytet, Institut derzhavnogo upravlinnya ta regionalynogo rozvitku, Uzhgorod, 2017, s. 97-100, ISBN 978-966-916-348-6 (Терзиев. В, Банабакова. В., Георгиев, М. Особенности, институции и значение развития рынка труда для достижения устойчивого экономического и социального развития. // Матеріали доповідей міжнародної науково - практичної конференції «Сучасні можливості забезпечення соціально-економічного розвитку країн» 16 вересня 2017 року, Міністерство освіти і науки України, Ужгородський національний університет, Факультет міжнародних економічних відносин, Економічний фракультет, Інститут державного управління та регіонального розвитку, Ужгород, 2017, с. 97-100, ISBN 978-966-916-348-6).

Terziev, V., Banabakova, V., Latyshev, O., Georgiev, M. (2017n). Opportunities of application of the balanced scorecard in management and control. // 3rd International Conference on Advances in Education and Social Sciences. International Organization Center of Academic Research, www.ocerint.org, 2017, pp. 773-791, ISBN: 978-605-82433-0-9.

Terziev, V., Nichev, N., Stoyanov, E., Georgiev, M. (20170). Key aspects of the problems of administrative control in Bulgaria. // Proceedings of ADVED 2017- 3rd International Conference on Advances in Education and Social Sciences 9-11 October 2017- Istanbul, Turkey. International Organization Center of Academic Research, www.ocerint.org, 2017, pp. 707-710, ISBN: 978-605-82433-0-9.

Terziev, V., Nichev, N., Stoyanov, E., Georgiev, M., Bogdanov, P. (2017p). Opportunities for strategic development of small business in Bulgaria. // Proceedings of ADVED 2017- 3rd International Conference on Advances in Education and Social Sciences 9-11 October 2017- Istanbul, Turkey. International Organization Center of Academic Research, www.ocerint.org, 2017, pp. 701-706, ISBN: 978-605-82433-0-9.

Terziev, V., Nichev, N., Stoyanov, E., Georgiev, M. (2017q). On some of the blank points in the application of administrative control in Bulgaria. // Proceedings of ADVED 2017- 3rd International Conference on Advances in Education and Social Sciences 9-11 October 2017- Istanbul, Turkey. International Organization Center of Academic Research, www.ocerint.org, 2017, pp. 695-700, ISBN: 978-60582433-0-9.

Terziev, V., Nichev, N., Stoyanov, E., Georgiev, M. (2017r). A general principle of the development process of Balanced scorecards as an instrument of control. // Proceedings of ADVED 2017- 3rd International Conference on Advances in Education and Social Sciences 9-11 October 2017- Istanbul, Turkey. International Organization Center of Academic Research, www.ocerint.org, 2017, pp. 690-694, ISBN: 978-605-82433-0-9.

Terziev, V., Latyshev, O., Georgiev, M. (2017s). Building competencies for social work through continuing vocational training. // Proceedings of ADVED 2017- 3rd International Conference on Advances in Education and Social Sciences 9-11 October 2017- Istanbul, Turkey. International Organization Center of Academic Research, www.ocerint.org, 2017, pp.754-772, ISBN: 978-605-82433-0-9.

Terziev, V., Latyshev, O., Georgiev, M. (2017t). Building competencies for social work through continuing vocational training. // IJAEDU- International E-Journal of Advances in Education, International Organization Center of Academic Research, www.ocerint.org, 3, 2017, N 9, pp. 638-659, e-ISSN: 2411-18.

Terziev, V., Nichev, N., Stoyanov, E., Georgiev, M. (2017u). A general principle of the development process of Balanced scorecards as an instrument of control. // IJAEDU- International E-Journal of Advances in Education, International Organization Center of Academic Research, www.ocerint.org, 3, 2017, N 9 , pp. 888-892, e-ISSN: 2411-18.

Terziev, V., Nichev, N., Stoyanov, E., Georgiev, M. (2017v). On some of the blank points in the application of administrative control in Bulgaria. // IJAEDU- International E-Journal of Advances in Education, International Organization Center of Academic Research, www.ocerint.org, 3, 2017, N 9, pp. 893-898, e-ISSN: $2411-18$

Terziev, V., Nichev, N., Stoyanov, E., Georgiev, M., Bogdanov, P. (2017w). Opportunities for strategic development of small business in Bulgaria. // IJAEDU- International E-Journal of Advances in Education, International Organization Center of Academic Research, www.ocerint.org, 3, 2017, N 9, pp. 903-908, e-ISSN: 2411-18. 
IJASOS- International E-Journal of Advances in Social Sciences, Vol. IV, Issue 12, December 2018

Terziev, V., Nichev, N., Stoyanov, E., Georgiev, M. (2017x). Key aspects of the problems of administrative control in Bulgaria. // IJAEDU- International E-Journal of Advances in Education, International Organization Center of Academic Research, www.ocerint.org, 3, 2017, N 9, pp. 909-912, e-ISSN: 2411-18.

Terziev, V., Banabakova, V., Latyshev, O., Georgiev, M. (2017y). Opportunities of application of the Balanced scorecard in management and control. // IJAEDU- International E-Journal of Advances in Education, International Organization Center of Academic Research, www.ocerint.org, 3, 2017, N 9, pp. 1056-1074, e-ISSN: 2411-18. 